\title{
Analyzing land surface temperature distribution in response to land use/land cover change using split window algorithm and spectral radiance model in Sundarban Biosphere Reserve, India
}

\author{
Mehebub Sahana $^{1} \cdot$ Raihan Ahmed $^{1} \cdot$ Haroon Sajjad ${ }^{1}$
}

Received: 18 April 2016/Accepted: 22 April 2016/Published online: 2 May 2016

(C) Springer International Publishing Switzerland 2016

\begin{abstract}
The paper utilized Landsat 5 TM and Landsat 8 OLI for analyzing land use/land cover change and its impact on land surface temperature in Sundarban Biosphere Reserve, India. Split window algorithm and spectral radiance model were used for determining land surface temperature from Landsat 8 OLI and Landsat $5 \mathrm{TM}$, respectively. The land use land cover change analysis revealed phenomenal increase in the waterlogged areas followed by settlement and paddy and a decrease in open forest followed by deposition and water body. The distribution of average change in land surface temperature shows that water recorded highest increase in temperature followed by deposition, open forest and settlement. Overlay of the transect profiles drawn on land use/land cover change map over land surface temperature map revealed that the land surface temperature has increased in those areas which were transformed from open forest to paddy, open forest to settlement, paddy to settlement and deposition to settlement. The study demonstrated that increase in non-evaporating surfaces and decrease in vegetation have increased the surface temperature and modified the temperature of the study area.
\end{abstract}

Keywords Land use changes - Land surface temperature · Split window algorithm - Spectral radiance model . Sundarban Biosphere Reserve

Haroon Sajjad

haroon.geog@gmail.com

1 Department of Geography, Faculty of Natural Sciences, Jamia Millia Islamia, New Delhi, India

\section{Introduction}

Large scale human activities are continuously decreasing the vegetative cover of the earth's surface. Consequently, the concentration of carbon dioxide is increasing in the atmosphere which in turn affecting the surface energy budget thereby producing changes in local, regional and global climate (Marland et al. 2003; Islam and Islam 2013). Such changes have far reaching implications for the health and resilience of ecosystems and for human society. Land surface temperature is one of the key parameters for estimating surface energy budget assessing land cover changes and other characteristics of the earth's surface (Srivastava et al. 2010). Review articles have demonstrated the impact of land use/land cover changes on land surface temperature distribution (Ahmed et al. 2013; Buyadi et al. 2013; Islam and Islam 2013; Julien et al. 2011). Various methods to measurement and analysis of surface temperature have been proposed by different authors using different approaches (Cristobal et al. 2009; Kumar et al. 2012; McMillin 1975; Rozenstein et al. 2014).

Intensity of climate change of Sundarban Biosphere Reserve is more than that of the global average and the surface temperature here is rising higher at the rate of $0.5^{\circ} \mathrm{C}$ per decade which is higher than the global average (Mitra et al. 2009). Living and non-living conditions of coastal environment are being drastically degraded due to large scale land use/land cover changes in Sundarban Biosphere (Mondal and Bandyopadhyay 2014). Rising sea surface temperature is directly related with the increased frequency and severity of cyclonic storms and depression in the Bay of Bengal. Mondal and Bandyopadhyay (2014) suggested that increasing trend in sea surface temperature may result in changes to the chemical composition of sea water, leading to increased acidification and decreased 
dissolved Oxygen level in Indian Sundarban. Many regions in south and south-eastern parts of the Reserve have been exposed to land erosion rendering poor people homeless. Sagar, Namkhana, and Pathar Pratima, Kakdwip blocks (administrative divisions of the district) are severely affected by the river encroachment (Bera 2013). Landscape of Indian Sundarban has experienced fast and remarkable changes in response to high population growth, soil erosion, bank embankment, deforestation and deposition within short span of time. These natural and man induced processes have modified the sea and land surface temperature of the region.

Measuring and analysing of surface temperature and surface emissivity by using remote sensing data and GIS analysis is virtually used by various scholars over the world. For example remote sensing and GIS techniques have been used to examine the effect of land use on land surface temperature in Netherlands by Jalili (2013), Hong Kong city, China by Liu and Zhang (2011), Dhaka Bangladesh by Ahmed et al. (2013) Al Habbaniyah, Lake by Sameen and Kubaisy (2014), Addis Ababa City, Ethiopia by Mbithi et al. (2010), Egypt by Omran (2012), Temperature modelling of Indus basin by Abbasi et al. (2012), Hyderabad city by Kumar et al. (2012), Delhi city by Mallick et al. (2010), Mahananda river basin by Srivastava et al. (2010), Dindigul drought prone district of Tamilnadu by Rajeshwari and Mani (2014), Indian Sundarban by Mondal and Bandyopadhyay (2014). This paper makes an attempt to analyze land use/land cover change and land surface temperature relationship in Sundarban Biosphere Reserve which is the home of distinct mangrove vegetation. This study makes a unique contribution as it analyzed a relation of land surface temperature with changing land use land cover in the study area The specific objectives of this study are (1) to examine the land use/land cover change (2) assessing land surface temperature change (3) to established the relationship of land use land cover change with land surface temperature.

\section{Study area}

Sundarban Biosphere Reserve (SBR) spreads over 13 blocks (administrative division of the district) of South 24 Parganas and 6 blocks of North 24 Parganas districts of West Bengal in India. It lies between $21^{\circ} 40^{\prime} 04^{\prime \prime} \mathrm{N}$ and $22^{\circ} 09^{\prime} 21^{\prime \prime} \mathrm{N}$ latitude, and $88^{\circ} 01^{\prime} 56^{\prime \prime} \mathrm{E}$ and $89^{\circ} 06^{\prime} 01^{\prime \prime} \mathrm{E}$ longitude (Fig. 1). Indian Sundarban Biosphere Reserve consists of $10,200 \mathrm{~km}^{2}$ of mangrove forest, $4200 \mathrm{~km}^{2}$ of reserved forest and another $5400 \mathrm{~km}^{2}$ inhabited region (Buffer and Transition zone of Sundarban Biosphere Reserve. The study area is bounded on the west by river Muriganga and on the east by rivers Harinbhahga and Raimangal. It is part of the tide dominated lower deltaic plain. The Sundarbans eco-region can be categorized into three distinct divisions - the beach/sea face, the swamp forests and the mature delta-based on the bio-geophysical attributes.

Indian Sundarban has been divided into three main broad geographical regions viz. core zone, buffer zone and transition zone. There are 102 islands comprising Indian Sundarban, out of which 54 are habited spread over buffer and transition zone of the biosphere reserve and balanced 48 islands are inhabited contain mangrove reserve forest. Although the region is situated south of the Tropic of Cancer, the temperature is moderate due to this region's proximity to the Bay of Bengal in the south. Average annual maximum air temperature is around $35^{\circ} \mathrm{C}$. The summer (pre-monsoon) extends from the middle of March to mid-June, and the winter (post-monsoon) from midNovember to February. The monsoon usually sets in around the middle of June and lasts up to the middle of October. Rough weather with frequent cyclonic depressions lasts from mid- March to mid-September. Average annual rainfall is $1920 \mathrm{~mm}$. Average humidity is about $82 \%$ and is more or less uniform throughout the year. Thirty-four true mangrove species and some 62 mangrove associated species are found here (Banerjee 2013). It is the home to 4.5 million people of India (Census of India 2011). Due to non availability of sweet water except in monsoon and soil salinity, agriculture is mono cropping in Sundarban Biosphere Reserve. People's life of Sundarban islands revolves around land, water and forest. Although agriculture remains a source of livelihood for the people living in islands, the brackishness of rivers makes agriculture unsuitable and uncertain. Winter cultivation is virtually non-existent for want of fresh water.

\section{Database and methodology}

Landsat Satellite image (LANDSAT 5 TM, 1990) and (LANDSAT 8 OLI, 2014) of Sundarban Biosphere Reserve were used for assessing land use changes and their impact on land surface temperature. The detailed methodology is reveled in Fig. 2 and the steps followed in methodology are presented in sub sections.

Land use land cover maps of the study area for 1990 and 2014 were generated by supervised classification and maximum likelihood method was used for this classification. The pixel sample ware selected from various spectral classes and run the data using maximum likelihood method. Final groping of similar pixels was done on the basis of sampled pixels for various land use/land cover classes. The generalized images were reclassified to reduce classification error and improve the accuracy of the classification. The overall accuracy of the classifications for 1990 and 2014 was assessed using confusion matrix and 


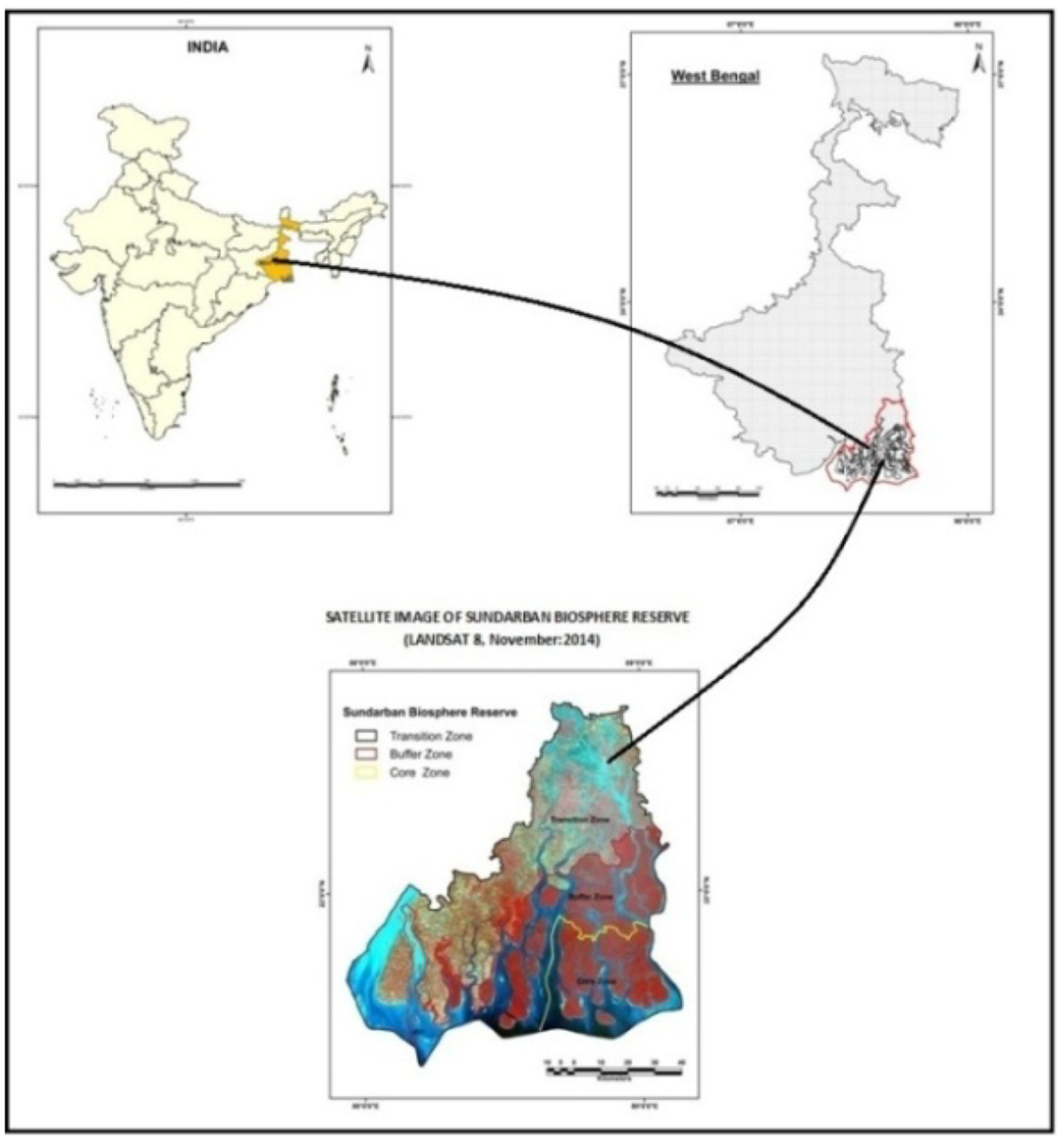

Fig. 1 Location of Sundarban Biosphere Reserve

was determined as 98.0 and $99.0 \%$, respectively. Land use/land cover change map was prepared using overlay function in Erdas Imagine.

Surface temperature was derived from geometrically corrected Landsat $5 \mathrm{TM}$ (band 6) and Landsat 8 TIRS (band 10 and 11). Spectral radiance model was used to retrieve surface temperature from Landsat $5 \mathrm{TM}$ and split- window method was used to retrieve surface temperature from LANDSAT 8 TIRS. A three step process was followed to derive surface temperature from Landsat TM 5 Image. Spectral radiance was calculated using following equation:

$L=L M I N+(L M A X-L M I N) \times D N / 255$ 


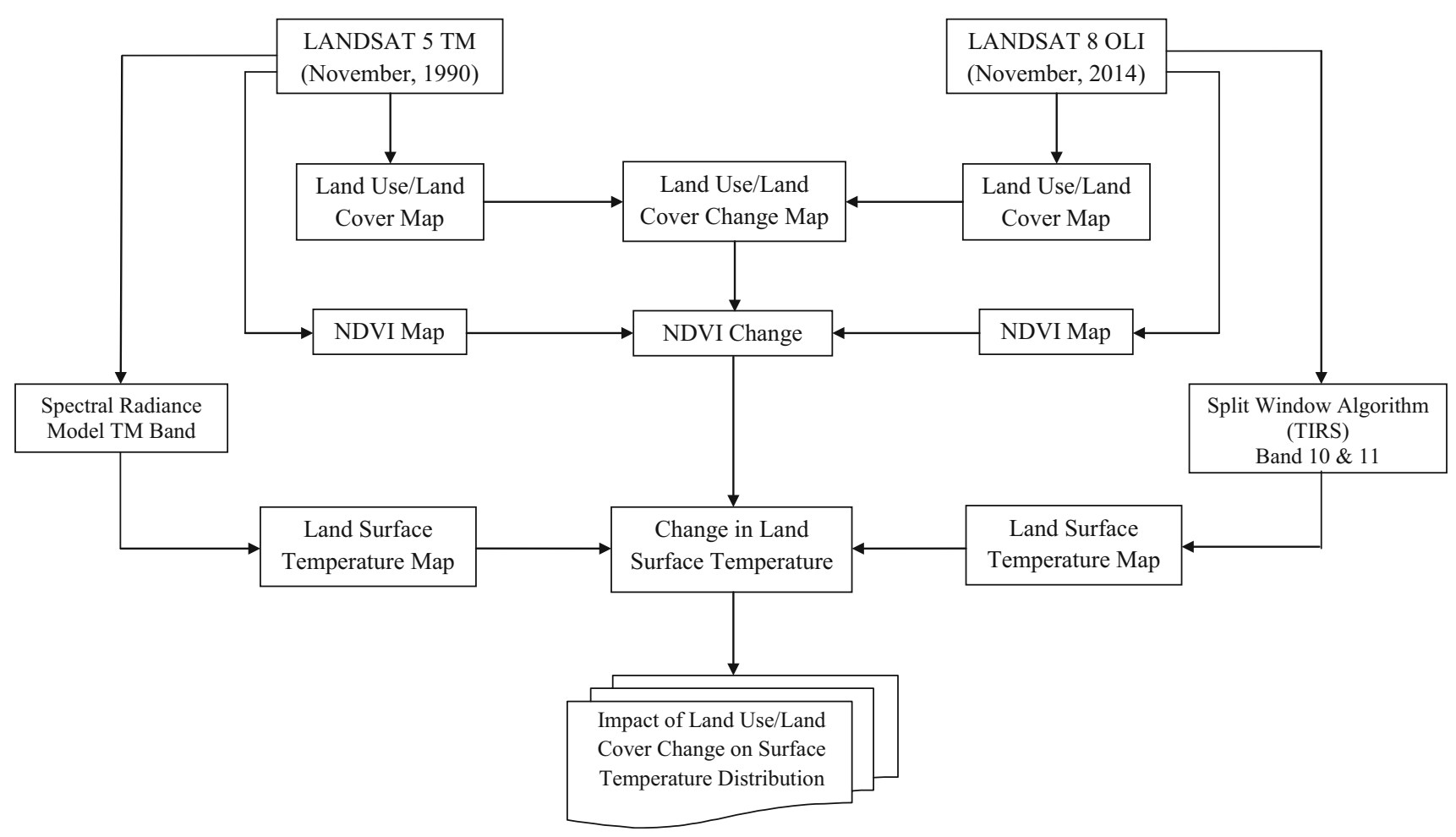

Fig. 2 Methodological framework adopted for analyzing variation in land surface temperature distribution in response to land use/land cover change using Split window Algorithm (TIRS, Landsat-8) and spectral radiance model (TM, Landsat-5) on Sundarban Biosphere Reserve, India

where $L=$ Spectral Radiance, $L M I N=1.238, L M A X=$ 15.600, $D N=$ Digital Number.

Spectral Radiance (L) to Temperature in Kelvin may be expressed as:

$T_{B}=\frac{K_{2}}{\ln \left(\frac{K_{1}}{L}+1\right)}$

where $\mathrm{K}_{1}=$ Calibration Constant 1 (607.76), $\mathrm{K}_{2}=$ Calibration Constant 1 (1260.56), $\mathrm{T}_{\mathrm{B}}=$ Surface Temperature

Surface temperature from Landsat 8 TIRS was derived using band 10 and 11 following the split-window method first proposed by Mc Millin in 1975.

The algorithm is:

$$
\begin{aligned}
L S T= & T B_{10}+C_{1}\left(T B_{10}-T B_{11}\right)+C_{2}\left(T B_{10}-T B_{11}\right) 2 \\
& +C_{0}+\left(C_{3}+C_{4} W\right)(1-\varepsilon)+\left(C_{5}+C_{6} W\right) \Delta \varepsilon
\end{aligned}
$$

where LST $=$ Land surface temperature, $\mathrm{C} 0-\mathrm{C} 6=$ Splitwindow coefficient values (Table 5), $\mathrm{TB}_{10}$ and $\mathrm{TB}_{11}=$ Brightness temperature of band 10 and band 11 , $\varepsilon=$ Mband 10 and band $11, \varepsilon=$ Mean LSE of TIR bands, $\mathrm{W}=$ Atmospheric water vapor content, $\Delta \varepsilon=$ Difference

\begin{tabular}{|c|c|c|}
\hline \multicolumn{2}{|l|}{ Constant } & Value \\
\hline \multicolumn{2}{|l|}{$\mathrm{C} 0$} & -0.268 \\
\hline \multicolumn{2}{|l|}{$\mathrm{C} 1$} & 1.378 \\
\hline \multicolumn{2}{|l|}{$\mathrm{C} 2$} & 0.183 \\
\hline \multicolumn{2}{|l|}{$\mathrm{C} 3$} & 54.3 \\
\hline \multicolumn{2}{|l|}{$\mathrm{C} 4$} & -2.238 \\
\hline \multicolumn{2}{|l|}{$\mathrm{C} 5$} & -129.2 \\
\hline \multicolumn{2}{|l|}{ C6 } & 16.4 \\
\hline Thermal constant & Band 10 & Band 11 \\
\hline $\mathrm{K}_{1}$ & 1321.08 & 1201.14 \\
\hline $\mathrm{K}_{2}$ & 777.89 & 480.89 \\
\hline Radiance multiplier $\left(\mathrm{M}_{\mathrm{L}}\right)$ & 0.0003342 & 0.0003342 \\
\hline Radiance add $\left(\mathrm{A}_{\mathrm{L}}\right)$ & 0.01 & 0.01 \\
\hline
\end{tabular}
in LSE .
The value of Top Atmospheric Spectral Radiance (TOAr) was determined by converting original DNs and TIRS into atmospheric radiance. The original Digital Numbers (DN) of Landsat 8 TIR is converted into radiance 
based on the methods provided by Chander and Markham (2003):

$T O A r=M_{L} \times D N+A_{L}$

where $\mathrm{A}_{\mathrm{L}}=$ Radiance add, $\mathrm{M}_{\mathrm{L}}=$ Radiance multiplier, $\mathrm{DN}=$ Digital number.

The Brightness temperature (TB) for both TIR bands was calculated by adapting the following formula:

$T B=\frac{K 2}{\operatorname{Ln}\left[\left(\frac{K 1}{T O A r}\right)+1\right]}$

where $\mathrm{K} 1$ and $\mathrm{K} 2=$ Thermal constant for TIR bands, $\mathrm{TB}=$ Brightness $\quad$ temperature,$\quad \mathrm{TOAr}=$ Atmospheric spectral radiance.

NDVI is a most widely used vegetation index for monitoring the earth's vegetation cover using satellite imagery. Here NDVI is calculated from the visible and near-infrared light reflected by vegetation cover. Leaf cells scatter (i.e., reflect and transmit) solar radiation in nearinfrared spectral region strong absorption would overheat the plant possibly damaging the tissues. Live green plants appear relatively dark in the PAR and relatively bright in the near-infrared. Clouds and snow tend to be rather bright in the red (as well as other visible wavelengths) and quite dark in the near-infrared.

NDVI is calculated from these individual measurements as follows:

$N D V I=(N I R-R e d) /(N I R+R e d)$
Red and NIR stand for the spectral reflectance measurements acquired in the red and near-infrared regions, respectively. NDVI itself thus varies between -1.0 and +1.0 .

A land surface transit profile was drawn to generalize the relationship between land use/land cover change and surface temperature distribution. Three transit profiles were generated in east to west direction in land surface temperature map. Land use and land cover maps were then overlaid on surface temperature transit profile. Land use/land cover relationship with surface temperature was established by overlaying land use/land cover change map on land surface temperature transit profile of current date.

\section{Results and discussion}

\section{Patterns of land use land cover changes}

Land use and land cover maps of Sundarban Biosphere Reserve for 1990 and 2014 are shown in Fig. 3. The total area of every land use category and percentage of each class between 1990 and 2014 were calculated and are presented in Table 1. Over the last 24 years there was a drastic and rapid increase in settlement and waterlogged area and a decrease in deposition and open forest area. One of the most conspicuous changes was noticed in waterlogged of upper part of the biosphere reserve which has gone up from 1.14 to $4.24 \%$ at the rate of $272 \%$ over the period. This change is (a)

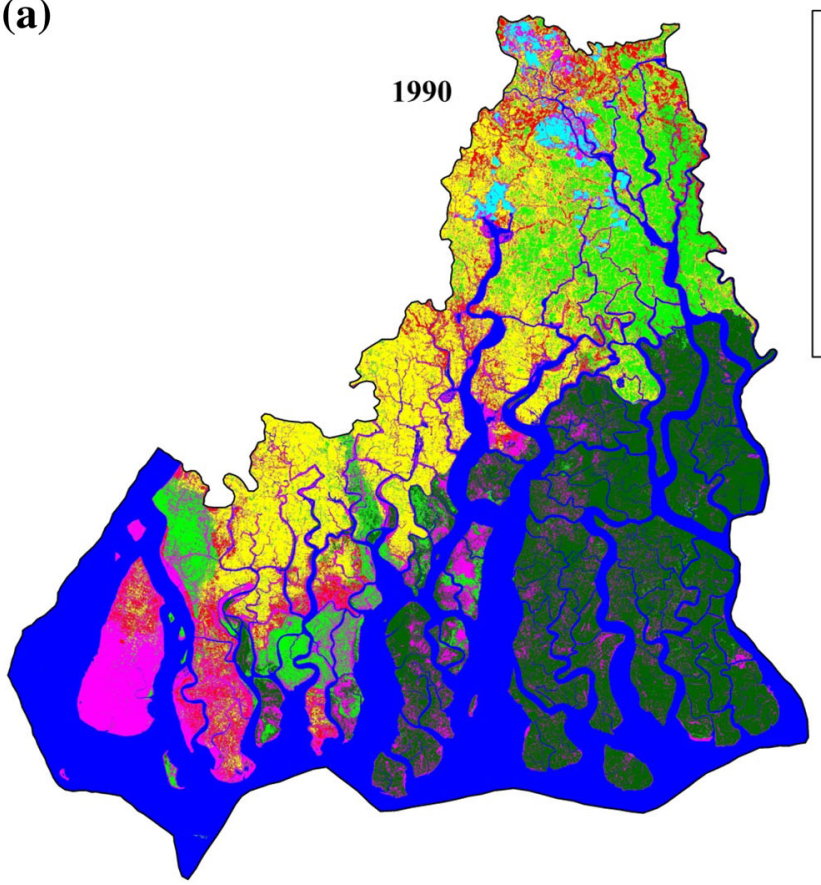

(b)
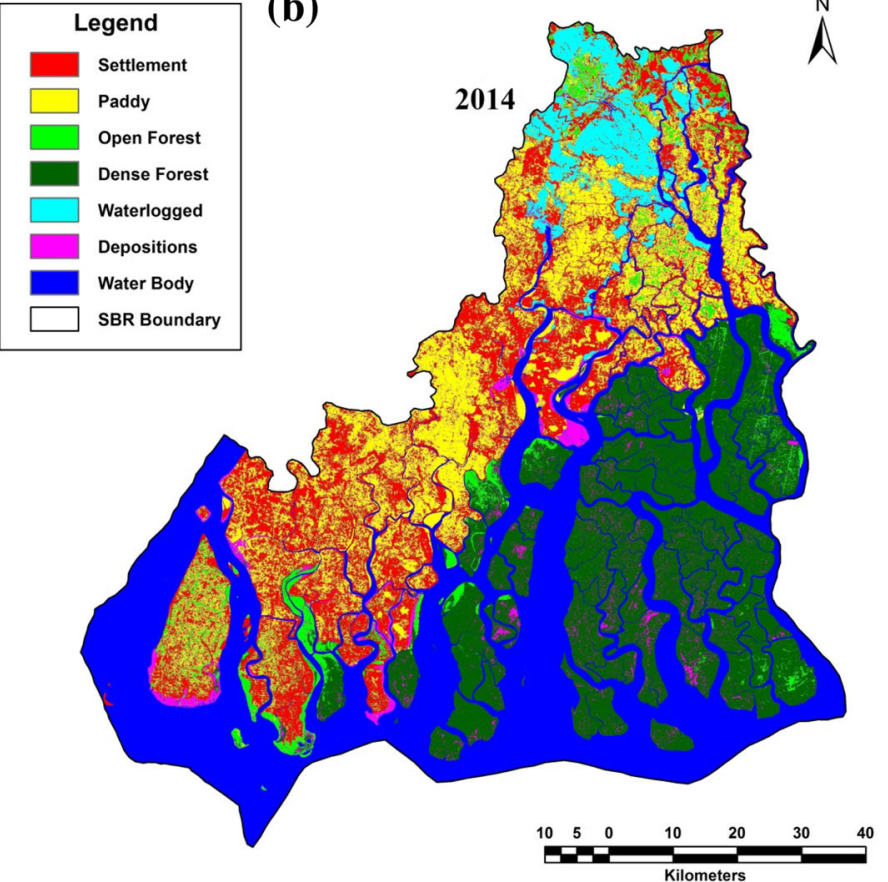

Fig. 3 Map obtained through overlying land use/land cover maps of 1990 and 2014. It is showing changes in land use/land cover classes during study period in Sundarban Biosphere Reserve. White colour is the unchanged area in the map 
Table 1 Area under land use/land cover classes (1990 and 2014)

\begin{tabular}{|c|c|c|c|c|c|c|}
\hline \multirow[t]{2}{*}{ LULC class } & \multicolumn{2}{|l|}{1990} & \multicolumn{2}{|l|}{2014} & \multicolumn{2}{|l|}{ 1990-2014 } \\
\hline & Area (ha) & $\%$ to total area & Area (ha) & $\%$ to total area & Change (ha) & Change in $\%$ \\
\hline Water body & $301,612.36$ & 34.28 & $29,3154.4$ & 33.32 & -8457.96 & -3 \\
\hline Deposition & $112,068.29$ & 12.74 & $17,519.36$ & 1.99 & $-94,548.93$ & -84 \\
\hline Waterlogged & $10,036.1$ & 1.14 & $37,313.57$ & 4.24 & $27,277.47$ & 272 \\
\hline Open forest & $91,252.28$ & 10.37 & $29,540.12$ & 3.36 & $-61,712.16$ & -68 \\
\hline Settlement & $45,238.51$ & 5.14 & $167,662.8$ & 19.06 & $122,424.29$ & 271 \\
\hline Paddy & $142,044.83$ & 16.14 & $145,966.07$ & 16.59 & 3921.24 & 3 \\
\hline Dense forest & $177,622.87$ & 20.19 & $188,718.92$ & 21.45 & $11,096.05$ & 6 \\
\hline Total & 879875.24 & & 879875.24 & & & \\
\hline
\end{tabular}

attributed to river erosion particularly in the northern part of the study area. The study further indicates that settlement area has increased from $5.15 \%$ in 1990 to $19.06 \%$ in 2014 registering an increase of $271 \%$ and indicating the land conversion and pressure on natural recourses of the study area. This change is remarkable in the transition and buffer zones and attributed to reckless cutting of open forest as a consequence of growth of population. The area under paddy cultivation has a slight increase at the rate of $3 \%$. This is mainly due to spread of salinity. Deposition area is found to be significantly reduced from 12.74 to $1.99 \%$ within the followed by open forest from $10.37 \%$ in 1990 to $3.36 \%$ in 2014 (Table 1. and Fig. 4). Land use/land cover change matrix shows that of the total area under deposition $(112068 \mathrm{~h}), 102133 \mathrm{~h}$ has been converted into settlement, dense forest, paddy, water body, open forest and waterlogged during 1990-2014 (Table 2.). Owing to the demand for settlement $59239 \mathrm{~h}$ paddy, $34652 \mathrm{~h}$ deposition and $24720 \mathrm{~h}$ open forest have been converted into settlement. A significant finding of the study is that $4098 \mathrm{~h}$ of settlement and $10758 \mathrm{~h}$ of paddy have been transformed into waterlogged area. This change is prevalent in the upper part of the study area due to frequent floods and tides. Nearly $6576 \mathrm{~h}$ of dense forest and $9071 \mathrm{~h}$ of settlement have been transformed into water body due to large scale erosion particularly in the lower part of the Sundarban islands. Open forests have been converted into paddy (46125 h) and settlement (24270 h). This shows that paddy has witnessed intensification mainly through the transformation of open forests.

\section{NDVI}

The NDVI values of the pixel vary between -1 and +1 . The highest values of NDVI more than 0.3 are indicate the richest or healthy vegetation. NDVI value like below 0 is indicate the water body and from 0.01 to 0.02 are non vegetated area followed by $0.02-0.03$ are unhealthy vegetation. According to Fig. 7 the healthy vegetation are decline in Sundarban Biosphere Reserve but the non vegetated cover are increase gradually over the time period. And a slight increase in unhealthy vegetation cover is shown by Fig. 5 . due to paddy cultivation in these seasons. In 1990 the NDVI range between -0.59 and +0.68 , which is gradually reduced to between -0.16 and 0.41 in 2014. Therefore, it can be said that the NDVI is decreasing in Sundarban Biosphere Reserve over the time.

\section{Changes in land surface temperature}

The average surface temperature of the study area has increased at the rate of $0.54{ }^{\circ} \mathrm{C}$ per decade. Table 1 shows that all the land use land cover classes identified recorded increase in the surface temperature over the study period. Spatio-temporal distribution of surface temperature shows that settlement has recorded the highest average temperature $20.77^{\circ} \mathrm{C}$ in 1990 and $21.86^{\circ} \mathrm{C}$ in 2014 followed by waterlogged $20.64{ }^{\circ} \mathrm{C}$ in 1990 and river deposition $20.98{ }^{\circ} \mathrm{C}$ in 2014 . This implies that growth of settlement does bring up surface temperature by replacing vegetation with non-evaporating surface. The lowest average temperature was recorded in water body is $18.03{ }^{\circ} \mathrm{C}$ in 1990 and $20.05{ }^{\circ} \mathrm{C}$ in 2014 followed by open forest $18.97{ }^{\circ} \mathrm{C}$ in $1990-20.57^{\circ} \mathrm{C}$ in 2014 and dense forest $19.13^{\circ} \mathrm{C}$ in 1990-20.80 ${ }^{\circ} \mathrm{C}$ in 2014 (Fig. 6 and Table 3). Vegetation shows a considerably low radiant temperature in both years because vegetation can reduce amount of heat stored in the soil and surface through transpiration. Vegetation has low temperature because the amount of heat stored is reduced through transpiration (Omran 2012). Surface temperature of water was low compared to other classes but the increase rate was high because the date of the data acquisition was November and the radiant reflected from the water body was lower than other objects in winter seasons. Rate of increase of surface temperature was highest over water body $\left(0.84{ }^{\circ} \mathrm{C}\right)$ followed by river deposition $\left(0.73{ }^{\circ} \mathrm{C}\right)$, dense forest $\left(0.69{ }^{\circ} \mathrm{C}\right)$, open forest $\left(0.67{ }^{\circ} \mathrm{C}\right)$ and settlement $\left(0.66^{\circ} \mathrm{C}\right)$. Waterlogged areas and paddy experienced low rate of temperature being 0.10 and $0.13{ }^{\circ} \mathrm{C}$, respectively (Table 4). 


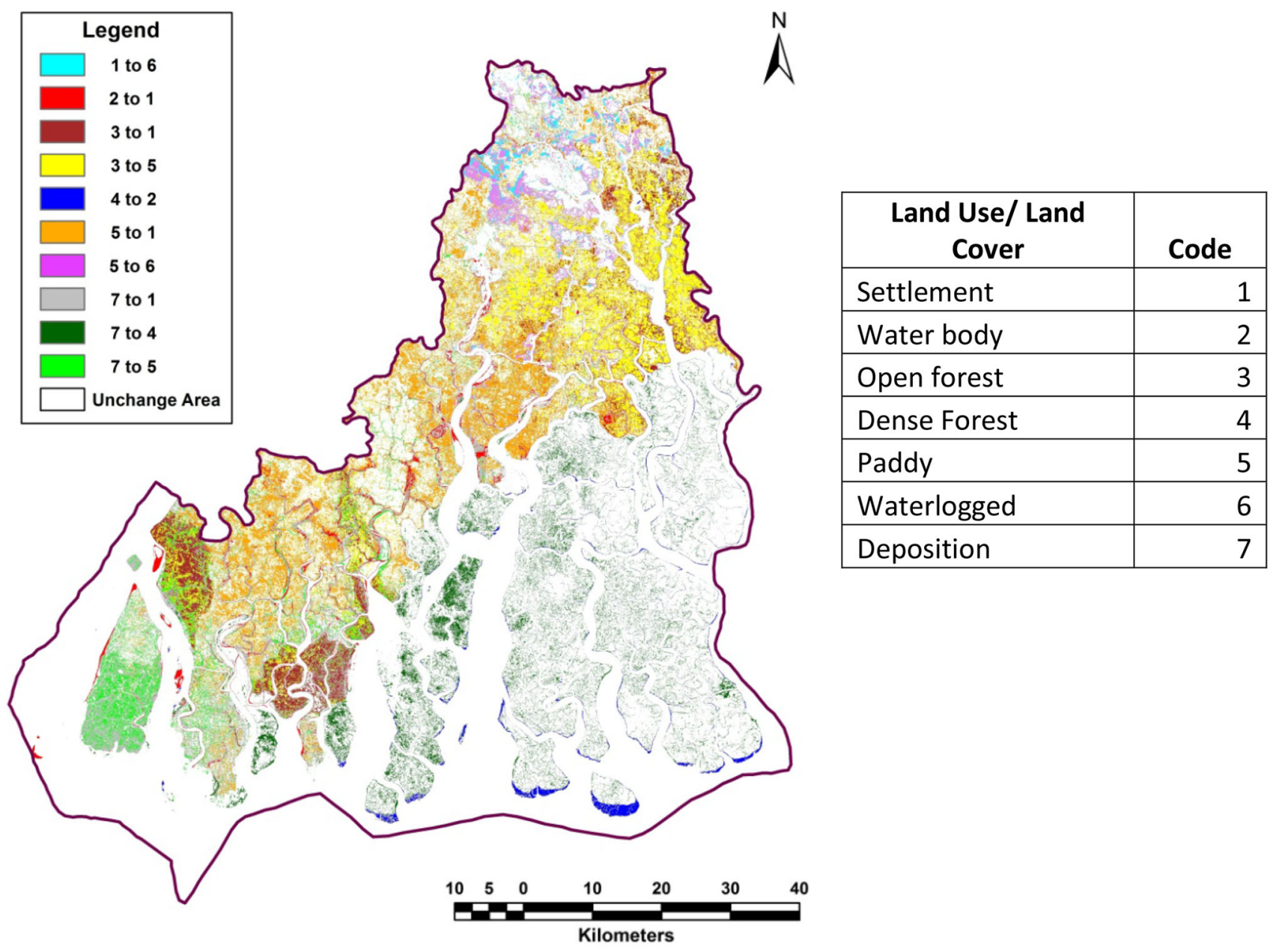

Fig. 4 Land use/land cover map of Sundarban Biosphere Reserve in Indian in 1990 (a) and 2014 (b) showing the different land use/land cover types

Table 2 Land use/land cover change matrix

\begin{tabular}{lcrcrrrrr}
\hline Class & Water body & Deposit & Waterlogged & Open Forest & Settlement & Paddy & Dense Forest & LULCC 1990 \\
\hline Water body & 275,784 & 1210 & 2437 & 2377 & 9071 & 4291 & 6442 & 301,612 \\
Deposition & 8078 & 9936 & 6301 & 7483 & 34,652 & 18,550 & 27,069 & 112,068 \\
Waterlogged & 241 & 100 & 7974 & 227 & 897 & 595 & 3 & 10,036 \\
Open forest & 1374 & 463 & 5676 & 7321 & 24,720 & 46,125 & 5574 & 91,252 \\
Settlement & 599 & 426 & 4098 & 1291 & 37,775 & 954 & 96 & 45,239 \\
Paddy & 503 & 348 & 10,758 & 3126 & 59,239 & 67,835 & 236 & 142,045 \\
Dense forest & 6576 & 5036 & 69 & 7716 & 1310 & 7616 & 149,299 & 177,623 \\
LULCC 2014 & 293,154 & 17,519 & 37,314 & 29,540 & 167,663 & 145,966 & 188,719 & 879,875 \\
\hline
\end{tabular}

\section{Land use/land cover change and land surface temperature relations}

Land use/land cover change map revealed that the surface temperature has increased at high rate in those areas where land use/land cover classes were converted to settlement.
Highest increase of temperature was observed where open forests were converted into settlement $\left(2.07{ }^{\circ} \mathrm{C}\right)$ followed by paddy to settlement $\left(1.80{ }^{\circ} \mathrm{C}\right)$ and deposition to settlement $\left(1.66^{\circ} \mathrm{C}\right)$ while a decrease of land surface temperature is observed where settlements were transformed into waterlogged $\left(0.19^{\circ} \mathrm{C}\right)$ (Table 5). 


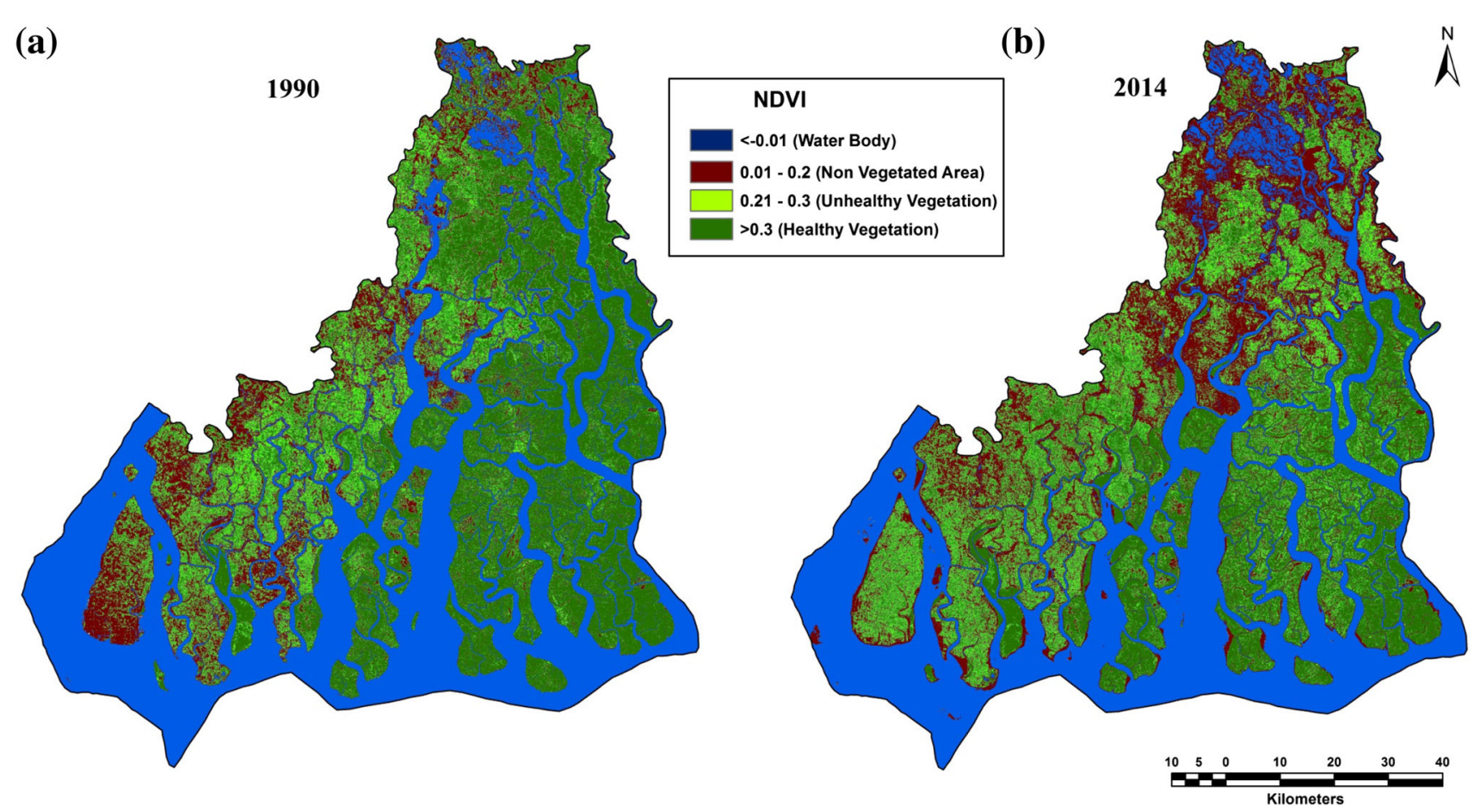

Fig. 5 Normalized different water index (NVDI) map of Sundarban Biosphere Reserve in 1990 (a) and 2014 (b) showing the four NDVI classes based on NDVI threshold values to identify the vegetation types within the study area

(a)

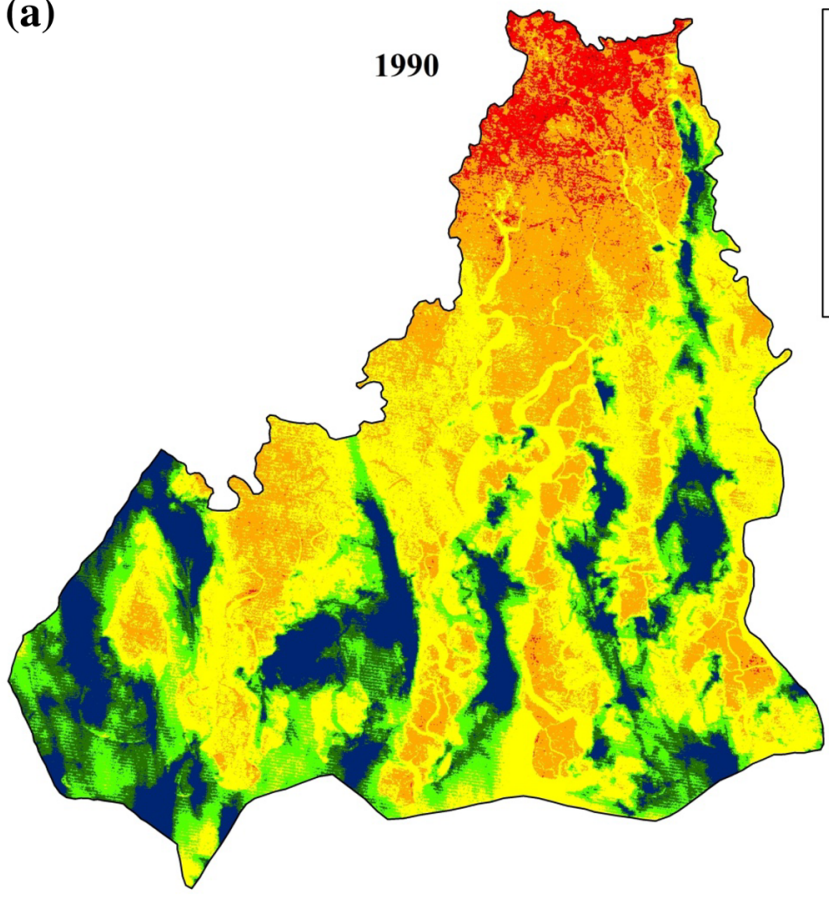

(b)
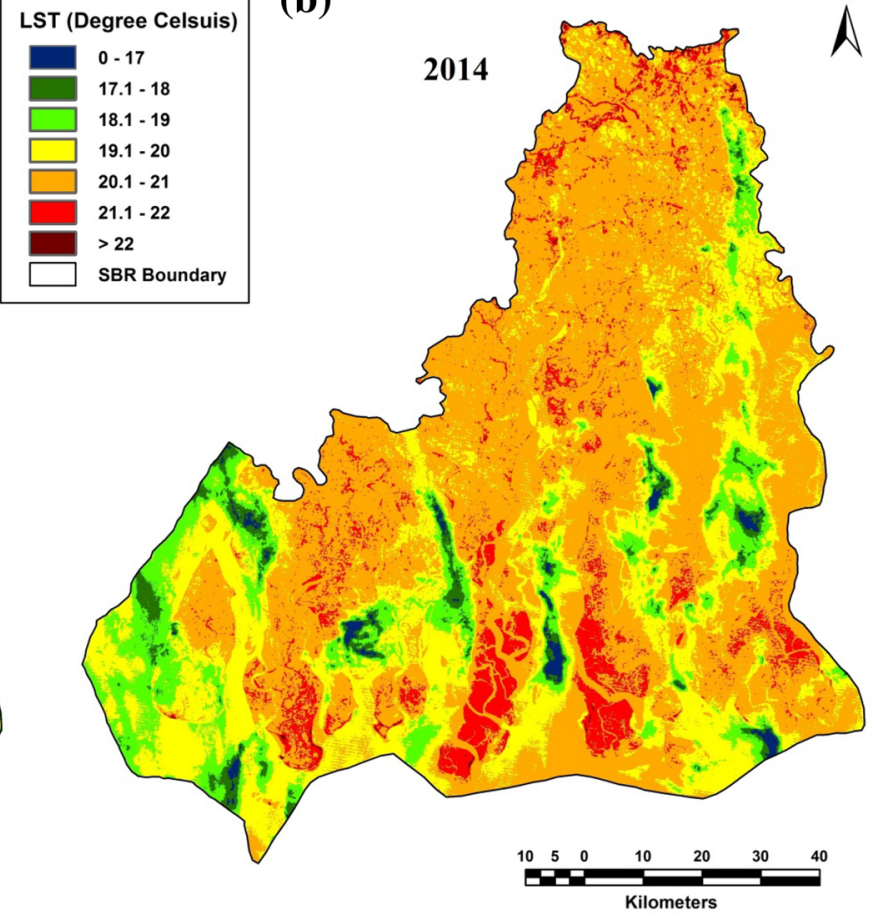

Fig. 6 Land surface temperature map of Sundarban Biosphere Reserve in 1990 (left) and 2014 (right) 
Table 3 Land surface temperature distribution over LULC classes 1990 and 2014

\begin{tabular}{|c|c|c|c|c|c|c|}
\hline \multirow[t]{3}{*}{ Land use land cover class } & \multicolumn{6}{|c|}{ Land surface temperature in ${ }^{\circ} \mathrm{C}$} \\
\hline & \multicolumn{3}{|l|}{1990} & \multicolumn{3}{|l|}{2014} \\
\hline & MIN & MAX & MEAN & MIN & MAX & MEAN \\
\hline Water body & 6.49 & 22.2 & 18.03 & 11.16 & 22.89 & 20.05 \\
\hline Deposition & 10.5 & 23.09 & 19.22 & 12.65 & 24.04 & 20.98 \\
\hline Waterlogged area & 17.2 & 22.64 & 20.64 & 13.69 & 23.52 & 20.87 \\
\hline Open forest & 6.49 & 22.2 & 18.97 & 10.32 & 25.11 & 20.57 \\
\hline Settlement & 11.48 & 23.09 & 20.37 & 15.91 & 25.6 & 21.86 \\
\hline Paddy & 17.66 & 22.64 & 20.33 & 15.65 & 22.94 & 20.64 \\
\hline Dense forest & 7 & 22.2 & 19.13 & 13.54 & 24.78 & 20.80 \\
\hline
\end{tabular}

Table 4 Nature of surface temperature increase in different land use/land cover classes

\begin{tabular}{llll}
\hline Class & Increase in ${ }^{\circ} \mathrm{C}$ & Yearly increase & Decadal increase \\
\hline Water & 2.02 & 0.08 & 0.84 \\
River deposits & 1.75 & 0.07 & 0.73 \\
Waterlogged & 0.23 & 0.01 & 0.10 \\
Open forest & 1.60 & 0.07 & 0.67 \\
Settlement & 1.59 & 0.07 & 0.66 \\
Paddy & 0.31 & 0.01 & 0.13 \\
Dense Forest & 1.67 & 0.07 & 0.69 \\
\hline
\end{tabular}

Three transit profiles were generated across the study area from east to west direction to validate the changes in surface temperature as a result of land use/land cover change (Fig. 7). It is seen from the profiles that surface temperature has increased due to transformation of land use/land cover classes into non-evaporating surfaces. Land surface temperature has increased due to transformation of deposition and open forest into settlement (Profile A), conversion of paddy into settlement (Profile $\mathrm{A}, \mathrm{B}$ and $\mathrm{C}$ ) while it has decreased due to transformation of settlement into waterlogged areas and conversion of open forest into paddy (Profile C). It is inferred from the analysis that surface temperature has increased in response to different land use/land cover changes in different zones of the study area. For example, in core area the temperature increased due to increase in deposition (Profile A). Buffer zone recorded high surface temperature due to transformation of open forest to settlement while in transition zone surface temperature has decreased only in those areas which are characterized with waterlogged areas.

Table 5 Change in surface temperature in response to land use/land cover changes

\begin{tabular}{|c|c|c|c|c|}
\hline $\begin{array}{l}\text { Land use land } \\
\text { cover change }\end{array}$ & $\begin{array}{l}\text { Area (In } \\
\text { hectares) }\end{array}$ & $\begin{array}{l}\text { Mean Temp. } \\
\left({ }^{\circ} \mathrm{C}\right) 1990\end{array}$ & $\begin{array}{l}\text { Mean Temp. } \\
\left({ }^{\circ} \mathrm{C}\right) 2014\end{array}$ & $\begin{array}{l}\text { Average change in land } \\
\text { surface temperature }\left({ }^{\circ} \mathrm{C}\right) \\
1990-2014\end{array}$ \\
\hline Water body to settlement & $90,198,736$ & 19.37 & 20.82 & 1.45 \\
\hline Deposition to dense forest & $269,051,330$ & 19.40 & 20.04 & 0.64 \\
\hline Deposition to settlement & $347,059,010$ & 19.10 & 20.76 & 1.66 \\
\hline Deposition to paddy & $185,510,590$ & 19.84 & 20.44 & 0.60 \\
\hline Open forest to settlement & $245,748,670$ & 17.96 & 20.03 & 2.07 \\
\hline Open forest to paddy & $422,815,100$ & 19.29 & 20.29 & 1.00 \\
\hline Settlement to waterlogged & $40,744,084$ & 21.24 & 21.05 & -0.19 \\
\hline Paddy to waterlogged & $107,567,890$ & 20.98 & 20.93 & -0.04 \\
\hline Paddy to settlement & $591,793,150$ & 19.30 & 21.10 & 1.80 \\
\hline Dense forest to water body & $64,019,920$ & 18.75 & 19.53 & 0.78 \\
\hline
\end{tabular}


Profile -A"
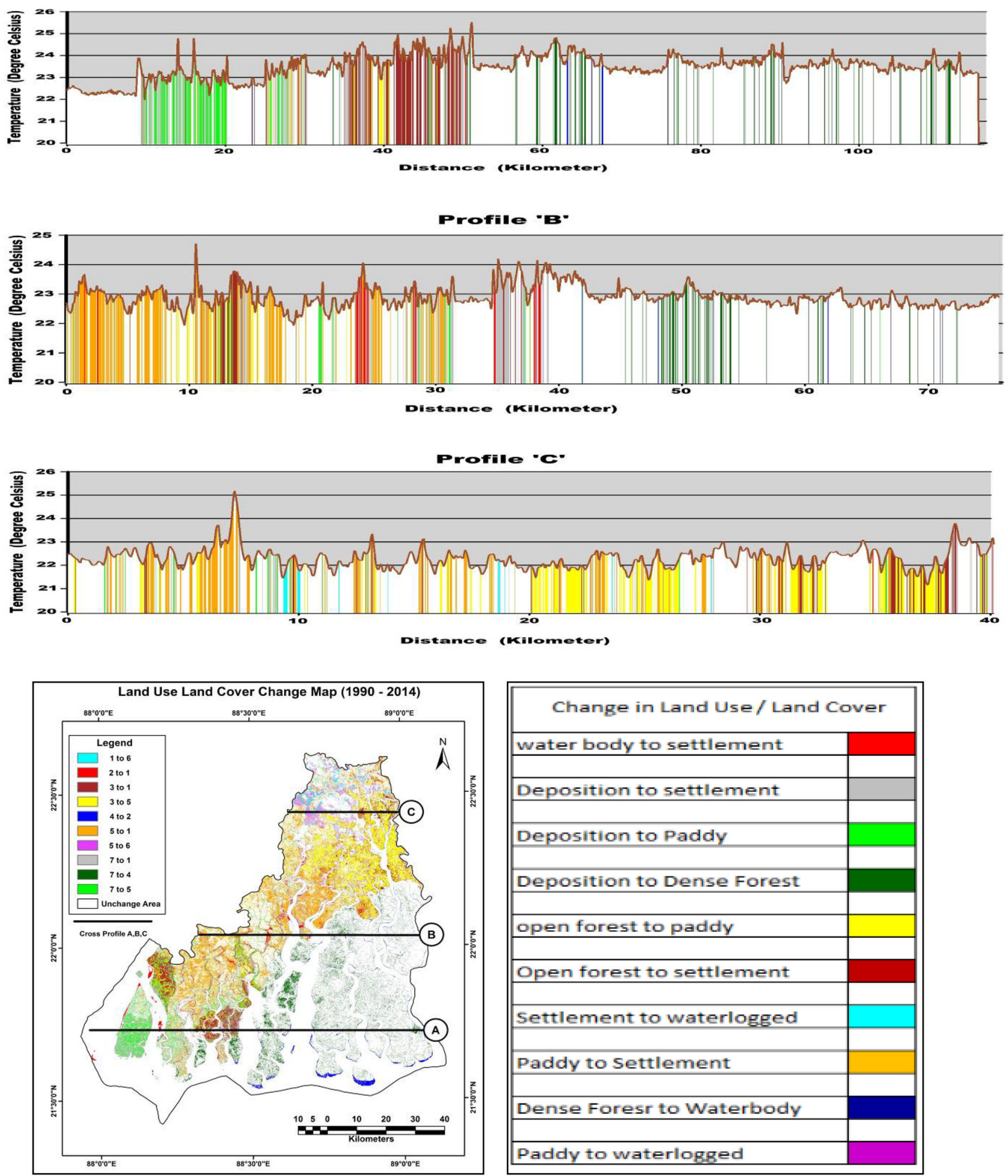

\begin{tabular}{|c|c|}
\hline \multicolumn{2}{|c|}{ Change in Land Use / Land Cover } \\
\hline water body to settlement & \\
\hline Deposition to settlement & \\
\hline Deposition to Paddy & \\
\hline Deposition to Dense Forest & \\
\hline open forest to paddy & \\
\hline Open forest to settlement & \\
\hline Settlement to waterlogged & \\
\hline Paddy to settlement & \\
\hline Dense Foresr to Waterbody & \\
\hline Paddy to waterlogged & \\
\hline
\end{tabular}

Fig. 7 The transect profile ( $A, B$ and $C$ ) were drawn for examining the relation of land surface temperature with land use land cover change. Transect profiles were drawn by overlying land use land cover change map on land surface temperature map (2014) 


\section{Conclusion}

The study demonstrates drastic changes in land use land cover in the study area. Surface energy budget of the study experienced alteration considerably in response to large scale land use/land cover changes. One of the distinct changes was observed in the northern part of the reserve where unprecedented increase in seasonal waterlogged area was recorded due to high tidal water. Another important change was observed as the expansion of settlement due to exponential growth of population. The area under paddy has increased to feed the million mouths. While open forest, deposition and water body experienced decrease in their respective areas. The changes in land use/land cover modified the radiant surface temperature and consequently surface energy budget. These changes in land surface temperature were validated by transect profiles and land use change map drawn in three parts of the study area. These profiles revealed that the land surface temperature has increased in those areas which are transformed from open forest to paddy, open forest to settlement, paddy to settlement and deposition to settlement. Thus, increase in non-evaporating surfaces and decrease in vegetation has increased the land surface temperature of the study area. Hence land surface temperature acts an important function of land use/land cover and modifies the temperature of surrounding areas.

\section{References}

Abbasi HU, Soomro AS, Memon A, Samo SR, Karas IR (2012) Temperature modelling of indus basin using landsat data. Sindh Univ Res J Sci Ser 44(2):177-182

Ahmed B, Kamruzzaman M, Zhu X, Rahman MS, Choi K (2013) Simulating land cover changes and their impacts on land surface temperature in Dhaka, Bangladesh. Remote Sens 5:5969-5998. doi:10.3390/rs5115969

Banerjee K (2013) Decadal change in the surface water salinity profile of Indian Sundarbans: a potential indicator of climate change. J Mar Sci Res Dev. doi:10.4172/2155-9910.S11-002

Bera MK (2013) Adaptation with social vulnerabilities and flood Disasters in Sundarban Region: a study of Lodha Tribes in Sundarban, West Bengal. Indian J Dalit Tribal Stud 1(2):49-62

Buyadi SNA, Mohd WMNW, Misni A (2013) Impact of land use changes on the surface temperature distribution of area surrounding the National Botanic Garden, Shah Alam. Procedia Soc Behav Sci 101:516-525

Census of India (2011) Primary Census Abstracts. Office of the Register General and Census Commissioner, Ministry of Home Affairs, Government of India

Chander G, Markham BL (2003) Revised Landsat-5 TM radiometric calibration procedures, and postcalibration dynamic ranges. IEEE Trans Geosci Remote Sens 41:2674-2677

Cristobal J, Munoz JCJ, Sobrino JA, Ninyerola M, Pons X (2009) Improvements in land surface temperature retrieval from the
Landsat series thermal band using water vapour and air temperature. J Geophys Res 114:08-103. doi:10.1029/ 2008JD010616

Islam MS, Islam KS (2013) Application of thermal infrared remote sensing to explore the relationship between land use-land cover changes and urban heat Island effect: a case study of Khulna City. J Bangladesh Inst Plan 6:49-60

Jalili SY (2013) The effect of land use on land surface temperature in the Netherlands." Lund University, GEM Thesis Series nr 1

Julien Y, Sobrino JA, Matter C, Ruesca AB, Jimenezmuno JC, Soria G, Hidalgo V, Atitar M, Franch B, Cuenca J (2011) Temporal analysis of normalized difference vegetation index (NDVI) and land surface temperature (LST) parameters to detect changes in the Iberian land cover between 1981 and 2001. Int J Remote Sens 32(7):2057-2068

Kumar KS, Bhaskar PU, Padmakumari K (2012) Estimation of land surface temperature to study urban heat Island effect using Landsat ETM + Image. Int J Eng Sc Technol 4(2):771-778

Liu L, Zhang Y (2011) Urban heat Island analysis using the Landsat TM data and ASTER data: a case study in Hong Kong. Remote Sens 3:1535-1552. doi:10.3390/rs3071535

Mallick J, Kant Y, Bharath BD (2008) Estimation of land surface temperature over Delhi using Landsat-7 ETM+. J Ind Geophys Union 12(3):131-140

Marland G, Pielke RAS, Apps M, Avissar R, Betts RA, Davis KJ, Frumhoff PC, Jackson ST, Joyce LA, Kauppi P, Katzenberger J, MacDicken KG, Neilson RP, Niles JO, Niyogi DDS, Norby RJ, Pena N, Sampson N, Xue Y (2003) The climatic impacts of land surface change and carbon management, and the implications for climate-change mitigation policy. Clim Policy 3:149-157

Mbithi DM, Demessie ET, Kashiri T (2010) The impact of Land Use Land Cover (LULC) Changes on Land Surface Temperature (LST); a case study of Addis Ababa City, Ethiopia. Kenya Meteorological Services, Laikipia Airbase, P.O. Box 192-10400 Nanyuki Town, Kenya

McMillin LM (1975) Estimation of sea surface temperatures from two infrared window measurements with different absorption. J Geophys Res 80:5113-5117

Mitra A, Gangopadhyay A, Banerjee K, Dube A, Schmidt A (2009) Observed changes in water mass properties in the Indian Sundarbans (northwestern Bay of Bengal) during 1980-2007. Curr Sci 97(10):1445-1452

Mondal I, Bandyopadhyay J (2014) Coastal zone mapping through geospatial technology for resource management of Indian Sundarban, West Bengal, India. Int $\mathbf{J}$ Remote Sens Appl 4(2):103-112

Omran ESE (2012) Detection of land-use and surface temperature change at different resolutions. J Geograph Inf Syst 4:189-203. doi:10.4236/jgis.2012.43024

Rajeshwari A, Mani ND (2014) Estimation of land surface temperature of Dindigul district using Landsat 8 data. Int J Res Eng Technol 3(5):122-126

Rozenstein O, Qin Z, Derimian Y, Karnieli A (2014) Derivation of land surface temperature for Landsat- 8 TIRS using a split window algorithm. Sensors 14:5768-5780. doi:10.3390/ s140405768

Sameen MI, Kubaisy MAA (2014) Automatic surface temperature mapping in ArcGIS using Landsat-8 TIRS and ENVI tools case study: Al Habbaniyah, Lake. J Environ Earth 4(12):12-17

Srivastava PK, Majumdar TJ, Bhattacharya AK (2010) Study of land surface temperature and spectral emissivity using multi-sensor satellite data. J Earth Syst Sci 11:67-74 